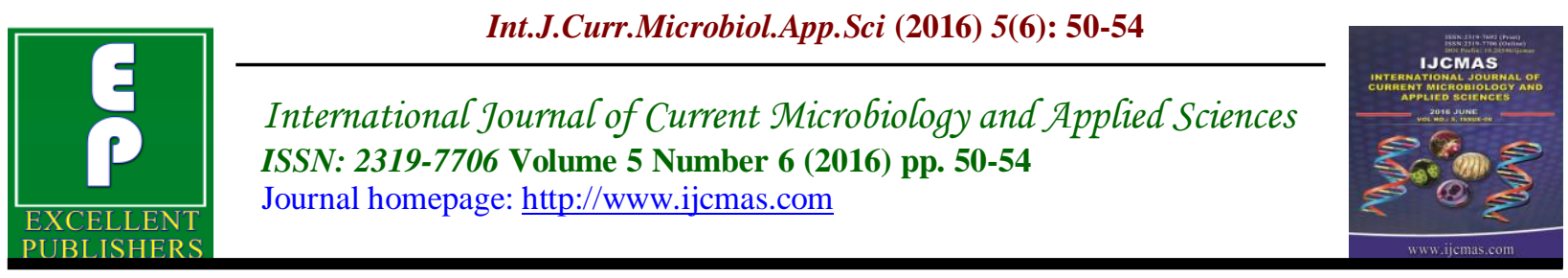

Original Research Article

http://dx.doi.org/10.20546/ijcmas.2016.506.006

\title{
High Prevalence of Human Rhinovirus in Pneumonia Suspected Children of Uttar Pradesh Region, India
}

\author{
Pooja Gaur ${ }^{1}$, Neena Srivastava ${ }^{2}$, Ravish Katiyar ${ }^{1}$, Nikky Nyari ${ }^{1}$, \\ Dharam Veer Singh ${ }^{1}$, Sneha Ghildyal ${ }^{1}$ and Tapan $\mathrm{N}^{\text {Dhole }}{ }^{1^{*}}$ \\ ${ }^{1}$ Department of Microbiology, Sanjay Gandhi Post Graduate Institute of Medical Sciences, \\ Lucknow - 226 014, Uttar Pradesh, India \\ ${ }^{2}$ Department of Physiology, King George’s Medical University, Chowk, \\ Lucknow- 226003, Uttar Pradesh, India \\ *Corresponding author
}

\section{A B S T R A C T}

\begin{tabular}{l} 
Key wor d s \\
Childhood \\
pneumonia, \\
Respiratory \\
infections, \\
Human \\
Rhinoviruses, \\
Mortality. \\
\hline Article Info \\
\hline Accepted: \\
07 May 2016 \\
Available Online: \\
10 June 2016
\end{tabular}

Childhood pneumonia is a common illness worldwide. Several bacteria and viruses can cause pneumonic illness among children. Respiratory viral infections are associated with childhood pneumonia up to $60 \%$ of the cases with high mortality rate. Human rhinoviruses (HRVs) associated pneumonia more likely to be occur in young children and older adults. The purpose of this study is to understand the prevalence of HRV in pneumonia suspected children of Uttar Pradesh region, using RT-PCR based molecular detection method. In this study $17.74 \%$ children are found HRV positive. Children of 0 to 5 year age group are found more susceptible to infection with high HRV prevalence (68\%). Clinical features of HRV confirmed pneumonic patients have been studied, among them $77 \%$ of patients were suffering from cough, followed by rhinitis $(68.2 \%)$, sputum (63.6\%), fever $(59 \%)$, chest pain $(54.5 \%)$ and shortness of breath (41\%). Children showed clinical symptom of shortness of breath were below 5 years of age.

\section{Introduction}

WHO reported that acute respiratory infections are responsible for approximate 2 million death rate in paediatric population per year (Le et al., 2012). In developing countries hospitalization, morbidity and mortality of children less than 5 years age group is mainly due to acute respiratory illness and pneumonia (Anh, et al., 2011; Igor, et al., 2008). The community acquired pneumonia is now a common problem in children caused either by several bacteria and viruses or their combination. Symptoms can include shortness of breath, coughing, fever, chills, chest pain and production of phlegm (Virkki et al., 2002). Diagnostic techniques for differentiation of viral pneumonia from bacterial pneumonia are required for proper treatment of pneumonia and decreasing unnecessary use of antibiotics (Virkki et al., 2002). Many viruses are responsible for serious respiratory illness such as influenza virus, respiratory syncitial virus (RSV), para 
influenza virus, coronavirus, human meta pneumovirus and human rhinoviruses (HRVs) etc. (Ann et al., 2006; Dat 2013). HRVs, the causative agents of various upper and lower respiratory tract infections including common cold and pneumonia, are small, ss RNA viruses, these are the member of Picornaviridae family and currently divided into two species HRV A, HRV B and more than 100 serotypes have been found (Lourenço et al., 2014; Neil et al., 2007; Kathryn et al., 2007). These HRVs as pathogen or co pathogen increase the severity of disease of respiratory infection mainly in case of bronchitis, bronchiolitis and pneumonia (Piotrowska Z. et al., 2009). One study reported that in developing countries, HRVs association found with severe pneumonia both in pediatric and adult population and also in immuno suppressed subjects (Olli et al., 2013). According to another report, $24 \%$ rhinovirus is associated with childhood pneumonia (Virkki et al., 2002). In some cases, HRVs are responsible for life threatening pneumonia (Nikolaos et al., 2002). The association of HRVs in pediatric pneumonia has been studied previously but its association with viral pneumonia among pediatric population of North Indian region is still unknown. The aim of this study is to analyse the prevalence of HRV with clinical features in pneumonia suspected children of Uttar Pradesh region.

\section{Materials and Methods}

\section{Sample Collection}

124 throat and nasal swab samples of Pneumonia suspected children of 0-15 years age group were collected from King George Medical University, Lucknow, Uttar Pradesh, India.

\section{Viral RNA Extraction}

The viral RNA extraction of samples was done using the Viral RNA extraction Kit
(QIAamp®, Qiagen) as per protocol provided with the kit.

\section{Molecular Screening by PCR}

$5 \mu l$ of extracted viral nucleic acid was used for viral screening by the technique RT-PCR using one-step RT-PCR Kit (AgPath-ID, Life Technologies), as per the manufacturer's instructions. The forward primer 5'-GGGACCAACTACTTTGGGTG TCCG-3' and reverse primer 5'-CACGG ACACCCAAAGTAGT-3' (Kiang D et al., 2008) were used to amplify within the 5 ' Non transcriptional region (5' NTR).

During the single step PCR, the conditions used as follows- reverse transcription for cDNA synthesis at $50^{\circ} \mathrm{C}(30$ minutes $)$, Initial denaturation $95^{\circ} \mathrm{C}(10$ minutes $)$, followed by 40 cycles of denaturation at $95^{\circ} \mathrm{C}$ (30 seconds), annealing at $55^{\circ} \mathrm{C}(30$ seconds) and elongation at $72^{\circ} \mathrm{C} \quad(45$ seconds).

\section{Agarose Gel Electrophoresis}

PCR products were loaded with gel loading dye and ethidium bromide on $1.5 \%$ agarose gel and run in TAE buffer. Products were visualized by use of ultraviolet illumination.

\section{Results and Discussion}

Here, we emphasized the involvement of human rhinoviruses in pneumonia among children of Uttar Pradesh region. In this study 124 throat and nasal swab samples of pneumonia suspected patients were examined by RT-PCR based molecular detection method using amplification of specific 5' Non transcriptional region (5'NTR) of viral RNA. 22 samples (17.74\%) were confirmed as HRV positive by RTPCR detection (figure-1), among them 63.6 $\%$ were male. 
Table.1 Clinical Features of HRV Confirmed Pneumonic Children

\begin{tabular}{|c|c|c|c|c|c|c|c|c|}
\hline $\begin{array}{c}\text { Sample } \\
\text { no. }\end{array}$ & Age & Sex & Cough & Sputum & Fever & Chest Pain & Rhinitis & $\begin{array}{c}\text { Shortness } \\
\text { of breath }\end{array}$ \\
\hline 5 & 3 year & Male & + & + & + & + & + & + \\
\hline 7 & 7 Year & Male & + & + & - & + & - & - \\
\hline 12 & 2 Year & Female & + & - & + & - & + & - \\
\hline 18 & 10 Year & Male & + & + & - & + & + & - \\
\hline 24 & 12 Year & Female & - & + & - & + & - & - \\
\hline 28 & 4 year & Male & + & + & + & + & + & - \\
\hline 42 & 9 month & Female & + & - & + & - & + & + \\
\hline 47 & 1 Year & Male & + & - & + & - & + & + \\
\hline 59 & 4 Year & Male & + & + & - & + & - & - \\
\hline 64 & 1 Year & Female & + & - & + & - & + & + \\
\hline 66 & 1.5 Year & Male & + & - & + & - & + & + \\
\hline 72 & 6 Year & Female & - & + & - & + & - & - \\
\hline 81 & 2 Year & Male & + & + & + & - & + & + \\
\hline 84 & 2 Year & Female & + & - & - & - & + & - \\
\hline 89 & 10 Year & Male & - & + & + & + & - & - \\
\hline 95 & 2.5 Year & Male & + & + & - & - & + & + \\
\hline 96 & 6 month & Male & - & - & + & - & + & - \\
\hline 102 & 3 Year & Female & + & + & + & + & + & - \\
\hline 109 & 11 Year & Male & - & + & - & + & + & - \\
\hline 111 & 7 year & Female & + & + & - & + & - & - \\
\hline 116 & 1 Year & Male & + & - & + & - & + & + \\
\hline 119 & 5 Year & Male & + & + & + & + & - & + \\
\hline & & & $17(77 \%)$ & $14(63.6 \%)$ & 13(59\%) & $\mathbf{1 2}(54.5 \%)$ & $\mathbf{1 5}(68 \%$ & $9(41 \%)$ \\
\hline
\end{tabular}

Fig.1 Gel Image Showing RT- PCR amplification of 5' NTR region of Human rhinovirus RNA. Lane M: Molecular marker1000 bp. Lane: 1, 6,7,9 PCR positive samples (400 bp).

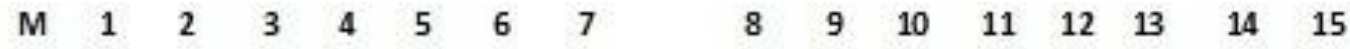

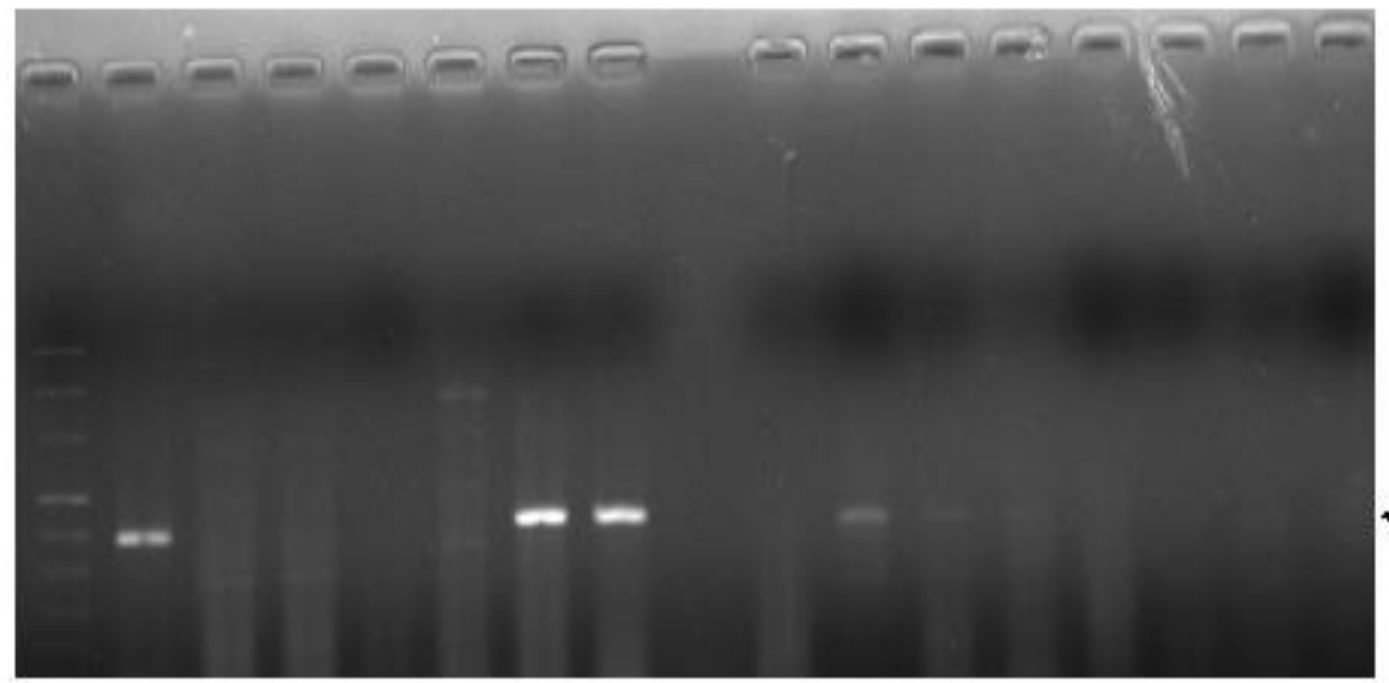


Fig.2 Percentage of HRV Positive Children with respect to age (years)

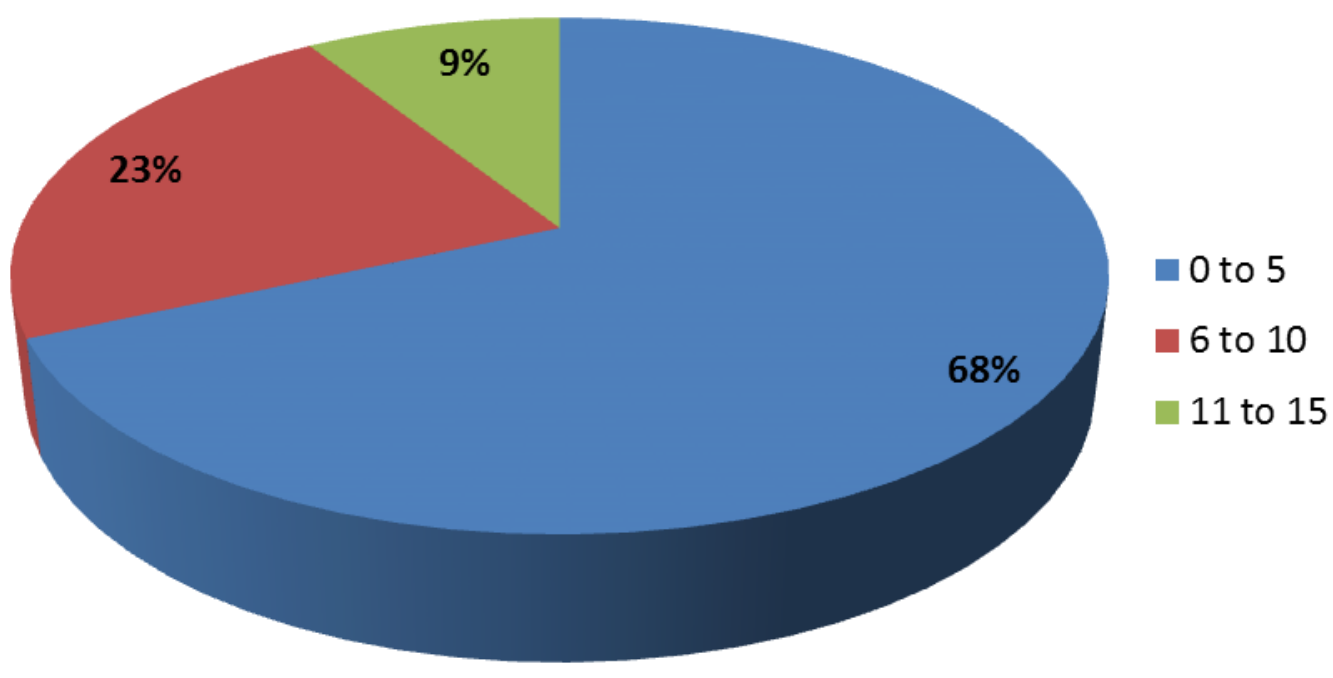

According to a previous study, In Italy 172 cases $(29 \%)$ are found HRV positive among 592 children with pneumonia (Esposito $e t$ al., 2012). In a study on pediatric pneumonia ( $\mathrm{N}=4279$ episodes) using PCR methods, HRV infection found in $18 \%$ of the cases (Ruuskanen et al., 2011). Recent studies reported $11 \%$ to $53 \%$ cases of HRV associated pneumonia among the hospitalized children (Ruuskanen et al., 2011; Honkinen et al., 2012). Younger children of $0-5$ years age group are found more susceptible for HRV infection. $68 \%$ of total HRV positive children were between 0 5 years of age. $23 \%$ children were 6 to 10 year old, while only $9 \%$ children were 11 to 15 year old (figure-2). Clinical features of HRV confirmed pneumonic patients have been studied. $77 \%$ of patients were suffering from cough, followed by rhinitis $(68.2 \%)$, sputum $(63.6 \%)$, fever (59\%), chest pain $(54.5 \%)$ and shortness of breath (41\%) (Table-1). Children suffering from Shortness of breath were between 0 to 5 year age group that indicates the severity of disease among younger children.

\section{Acknowledgement}

We are thankful to WHO for financial support in this study. We are also thankful to Mr. Saurabh Kumar dwivedi for valuable support.

\section{Reference}

Anh, H.L.D., Rogier, V.D., My, N.N., Juliet, E.B., Thanh, H.T.H., Quang, H.D., Tan, L.V., Tan, T.T., Bridget, W., Vinh, C.N., Minh, H., Cong, K.V., Minh, D.N., Jeremy, F.T.H.T., Menno, D.J. 2011. Viral etiologies of acute respiratory infections among hospitalized vietnamese children in Ho chi minh city, 2004-2008. PLoS One, 6: e18176.

Ann, R.F., Edward, E.W. 2006. Viral pneumonia in older adults. Aging and Infect. Dis., 42: 518-524.

Dat, T. 2013. Respiratory viral coinfection and clinical disease severity. $J$. Pediatr., 89(5): 421-423. 
Esposito, S., Daleno, C., Tagliabue, C., et al. 2012. Impact of rhinoviruses on pediatric community-acquired pneumonia. Eur. J. Clin. Microbiol. Infect. Dis., 31: 1637-1645.

Honkinen, M., Lahti, E., Österback, R., et al. 2012. Viruses and bacteria in sputum samples of children with community-acquired pneumonia. Clin. Microbiol. Infect., 18: 300-307.

Igor, R., Cynthia, B.P., Zrinka, B., Kim, M., Harr, C. 2008. Epidemiology and etiology of childhood pneumonia. Bull. World Health Organization, 86(5): 408-418.

Kathryn, M., Xiaoyan, L., Dean, D.E., Katherine, A.P., Yuwei, Z., Marie, R.G., Tina, V.H., Larry, J.A., Geoffrey, A.W., Caroline, B.H., Marika, K.I., Kathryn, M.E. 2007. Rhinovirus-associated hospitalizations in young children, for the new vaccine surveillance network. J. Infect. Dis., 195: 773-81.

Le, T.H., Vu, T.N.B., Le, K.N., Nguyen, T.N.D., Phan, H.P., Viet, P.H., Walter, R.T., Peter, H., Nguyen, T.L., Heiman, F.L.W. 2012. Fatal respiratory infections associated with rhinovirus outbreak, Vietnam. Emerg. Infect. Dis., 18: 1886-1888.

Lourenço, F.C., Divina, A.O.Q., Hélio, L.S., Morun, B.N., Nayhanne, T.P., Thelma, F.M.S.O, Aline, L.T., Jonny, Y. 2014. Human rhinovirus and disease severity in children. Pediatrics, 133: 312-321.
Neil, R., Brunhilde, S., Vishal, K., Zhiqiang, L., Joseph, V., Reinhard, B., Robert, M., Thomas, B., Lipkin, W.I. 2007. A recently identified rhinovirus genotype is associated with severe respiratory tract infection in children in Germany. J. Infect. Dis., 196: 1754-60.

Nikolaos, G.P., Maria, M., Mariza, T., Apostolos, B., Eleni, A., Anargiroula, P., Dimitrios, G., Dimitrios, K. 2002. Association of Rhinovirus Infection with Increased Disease Severity in Acute Bronchiolitis. Am. J. Respir. Crit. Care Med., 165: 1285-1289.

Olli, R., Matti, W., Octavio, R. 2013. New aspects on human rhinovirus infections. Pediatric Infect. Dis. J., 32: 553-555.

Piotrowska, Z., Vazquez, M., Shapiro, E.D. et al. 2009. Rhinoviruses are a major cause of wheezing and hospitalization in children less than 2 years of age. Pediatric Infect. Dis. J., 28: 25-29.

Ruuskanen, O., Lahti, E., Jennings, L.C. et al. 2011. Viral pneumonia. Lancet, 377: 1264- 1275.

Virkki, R., Juven, T., Rikalainen, H., Svedström, E., Mertsola, J., Ruuskanen, O. 2002. Differentiation of bacterial and viral pneumonia in children. Thorax, 57: 438-441.

Kiang, D., Kalra, I., Yagi, S., Louie, J.K., Boushey, H., Boothby, J. et al. 2008. Assay for 5' noncoding region analysis of all human rhinovirus prototype strains. J. Clin. Microbiol., 46(11): 3736-45.

\section{How to cite this article:}

Pooja Gaur, Neena Srivastava, Ravish Katiyar, Nikky Nyari, Dharam Veer Singh, Sneha Ghildyal and Tapan N Dhole. 2016. High Prevalence of Human Rhinovirus in Pneumonia Suspected Children of Uttar Pradesh Region, India. Int.J.Curr.Microbiol.App.Sci. 5(6): 50-54. doi: http://dx.doi.org/10.20546/ijcmas.2016.506.006 